Parsons, Y. M. and K. L. Shaw (2001): Species boundaries and genetic diversity among Hawaiian crickets of the genus Laupala identified using amplified fragment length polymorphism. Molecular Ecology 10: 1765-1772.

RoHLF, F. J. (1998): NTSYSpc: Numerical taxonomy and multivariate analysis system ver. 2.0. Departament of Ecology and Evolution, State University of New York, USA.

Rokas, A., B. L. Williams, N. King and S. B. CArroll (2003): Genome-scale approaches to resolving incongruence in molecular phylogenies. Nature 425: 798-804.

ROUPPE VAN DER VOORT, J. N. A. M., P. VAN ZANDVOORT, H. J. van Eck, R. T. Folkertsma, R. C. B. Hutten, J. Draaistra, F. J. Gommers, E. Jacobsen, J. Helder and J. BAKKER (1997): Use of allele specificity of comigrating AFLP markers to align genetic maps from different potato genotypes. Molecular Genetics and Genomics 255: 438-447.

RYDin, C. and N. WiströM (2002): Phylogeny of Isoëtes (Lycopsida): resolving basal relationships using $r b c L$ sequences. Taxon 51: 83-89.

Schneider, S., D. Roessli and L. Excoffier (2000): Arlequin ver. 2.000: A software for population genetics data analysis. Genetics and Biometry Laboratory, University of Geneva, Switzerland.

Setoguchi, H., T. A. Osawa, J.-C. Pintaud, T. Jaffré and J.-M. VeILlon (1998): Phylogenetic relationships within Araucariaceae based on $r b c L$ gene sequences. American Journal of Botany 85: 1507-1516.

SwOFFoRD, D. L. (1998): PAUP*: Phylogenetic analysis using parsimony and other methods. Illinois Natural History Survey, Champaing, IL.
Stefenon, V. M. and R. O. NodARI (2003): Marcadores moleculares no melhoramento genético de araucária. Biotecnologia Ciência e Desenvolvimento 31: 95-99.

Stefenon, V. M., R. O. Nodari and M. S. Reis (2003): Padronização de protocolo AFLP e sua capacidade informativa para análise da diversidade genética em Araucaria angustifolia. Scientia Forestalis 64: 163-171.

Stockey, R. A. and T. N. TAYLOR (1978): On the structure and evolutionary relationships of the Cerro Quadrado fossil conifer seedlings. Botanical Journal of the Linnean Society 76: 161-176.

Stockey, R. A. (1982): The Araucariaceae: an evolutionary perspective. Review of Paleobotany and Palynology 37: 133-154.

Stockey, R. A. (1994): Mesozoic Araucariaceae: morphology and systematics relationships. Journal of Plant Research 107: 493-502.

Vos, P., R. Hogers, M. Bleeker, M. Reijans, T. Lee, M. Hornes, A. FriJters, J. Pot, J. Peleman, M. Kuiper and M. ZABEAU (1995): AFLP: a new technique for DNA fingerprinting. Nucleic Acids Research 23: 4407-4424.

WANG, X.-R., Y. Tsumura, H. Yoshimaru, K. NAGAsaka and A. E. SzimdT (1999): Phylogenetic relationships of Eurasian pines (Pinus, Pinaceae) based on chloroplast rbcL, matK, rpl20-rps18 spacer, and trnV intron sequences. American Journal of Botany 86: 1742-1753.

Weising, K., H. NYBom, K. WolfF and G. KaHL (2005): DNA fingerprinting in plants: principles, methods, and applications. CRC Press, Boca Raton/FL.

\title{
Short Note: Crossability Between Pinus uliginosa and its Putative Parental Species Pinus sylvestris and Pinus mugo
}

\author{
By A. LewANDOWsKi and M. WiśniewsKa
}

Institute of Dendrology, Polish Academy of Sciences, Parkowa 5, 62-035 Kórnik, Poland. Corresponding author: e-mail: alew@rose.man.poznan.pl; tel. +48 061 8170033, fax: +48 0618170166

(Received 19 ${ }^{\text {th }}$ June 2005)

\begin{abstract}
Results of artificial fertilization of $P$. uliginosa with $P$. sylvestris and P. mugo are presented and discussed. $P$. sylvestris and $P$. mugo are thought to be the parental species of $P$. uliginosa. Two grafts of one $P$. uliginosa clone from Arboretum of the Institute of Dendrology in Kórnik, Poland were used as mother individuals. One individual of $P$. sylvestris and one individual of $P$. mugo were the pollen donors. Three mature cones were obtained as the result of artificial pollination of $P$. uliginosa with $P$. mugo pollen. Out of 107 seeds, 68 were filled what gives $63 \%$. P. uliginosa conelets pollinated
\end{abstract}

with $P$. sylvestris pollen were all aborted. Based on obtained data, close phylogenetic relationship between $P$. uliginosa and $P$. mugo complex is suggested.

Key words: P. uliginosa, P. sylvestris, P. mugo, hybridization, pollination, crossability.

\section{Introduction}

Dwarf mountain pine complex (Pinus mugo Turra complex) is well known for its taxonomically perplexing pattern of phylogenetic relations and contradictory views on taxonomic rank of taxons belonging to this 
complex. It consists of group of closely related taxons of Sylvestres subsection.

Peat-bog pine (Pinus uliginosa Neumann) is included to Pinus mugo complex. It is one out of four native pines in Poland. It is highly endangered species, due to decreasing population size and lack of natural regeneration. Additionally, sympatric occurrence with Scots pine (Pinus sylvestris L.) and overlapping of flowering periods for $P$. uliginosa and $P$. sylvestris may lead to gene pool erosion, as a consequence of interspecific fertilization (BORATYŃSKI et al., 2003; DANIELEWICZ and ZIELIŃSKI, 2000; LEWANDOWSKI et al., 2002).

The taxonomic rank and phylogenetic position of $P$. uliginosa is still not definitively described. Although the majority of researchers agree with putative hybrid derivation of $P$. uliginosa, they point out different putative parental species. In taxonomic revision of $P$. mugo complex, CHRISTENSEN (1987) and BUSINSKÝ (1999) classified peat-bot pine as synonym for Pinus rotundata and described it as a hybrid between $P$. mugo and $P$. uncina$t a$. Some other authors consider $P$. uliginosa as a result of an ancient hybridization between $P$. sylvestris and $P$. mugo (STASzKIEWICZ and TyszKiewicz, 1969; KRZAKOWA et al., 1984; LEWANDOWsKI et al., 2000). Despite genetic differences separating dwarf mountain pine and Scots pine, there are some studies indicating the possibility of artificial crossings (MARCET, 1967; MoulALIS et al., 1976; KORMUTAK and LANAKOWA 1988). Additionally, natural hybridization is reported in some mixed stands and hybrids are recognized as Pinus x rhaetica (CHRIsTENSEN, 1987).

In this paper, we present the results of controlled pollination $P$. uliginosa, with $P$. sylvestris and $P$. mugo. We intended to verify the crossability between these species in the aspect of possible natural hybridization and hybrid origin of peat-bog pine.

\section{Materials and Methods}

Two 6 years old grafts of one $P$. uliginosa clone from Arboretum of the Institute of Dendrology in Kórnik, Poland were used as mother individuals. These grafts were gained from Batorów Great Peatland, Sudety Mts., Poland. One individual of $P$. sylvestris and one individual of $P$. mugo were the pollen donors. Both paternal individuals came from the same Arboretum. Controlled crosses were carried out in May 2003. Two weeks before expected flowering time, female strobili were isolated with polyethylene bags to prevent unwilling crosses. Two days before pollination, pollen from Scots pine and Dwarf pine was collected. Pollen was applied into the bags by medicine dropper with a robber blower. Pollination was repeated in subsequent three days.

Five female strobili of one $P$. uliginosa graft were pollinated with $P$. sylvestris pollen and four female strobili of another $P$. uliginosa graft were pollinated with pollen of $P$. mugo. Male strobili on peat-bog pine grafts were absent, so self-fertilization was excluded.

\section{Results and Discussion}

The result of artificial pollination of $P$. uliginosa with $P$. mugo pollen were three mature cones. One conelet out of four was aborted due the mechanic damage. Out of 107 obtained seeds, 68 were filled what gives $63 \%$. Peatbog conelets pollinated with Scots pine pollen were all aborted next spring in 2004 .

Although the experiment is based on a rather limited material, the results have provided an interesting information which may facilitate the discussion on the hybrid origin and taxonomic position of P. uliginosa. Morphological and anatomical studies indicate distinctness of $P$. uliginosa from the closely related species Scots pine and they also show some similarities to dwarf mountain pine. Moreover, P. uliginosa individuals with intermediate or mixed phenotype with regard to Scots pine and dwarf mountain pine were reported (PRUSGLOWACKI and SzWEYKOWSKI, 1980; STASZKIEWICZ, 1993). Intermediate position of $P$. uliginosa between $P$. sylvestris and P. mugo was also noted in biochemical studies, what can suggest hybrid derivation (PRUsGLOWACKI and SzWEYKOWSKI, 1983; LEWANDOWSKI et al., 2000; LEWANDOWSKI et al., 2002). Hybrid individuals frequently maintain ability to backcross with one or both parental species. Results of crossings between peat-bog pine with close related dwarf mountain pine reported in this paper, were very successful. Gene flow between $P$. uliginosa and P. mugo is supposed to take place also in natural stands, although there is no reliable method to confirm this. PCR-RFLP analyses of cpDNA trnV-rbcL region enable distinguishing $P$. sylvestris from $P$. mugo complex, but it becomes ineffective in case of distinguishing $P$. uliginosa from $P$. mugo (WACHOWIAK et al., 2004). Contrary, lack of crossability between $P$. uliginosa and $P$. sylvestris observed in this survey indicates the existence of reproductive barriers. However, WACHOWIAK et al. (2005) has recently reported about $1 \%$ of hybrid individuals among $P$. uliginosa seeds from natural stand at WEsGLINIEC, surrounded by extensive stands of $P$. sylvestris.

Despite the reproductive barriers between $P$. sylvestris and $P$. mugo found in this study, the unequivocal excluding of $P$. sylvestris contribution in $P$. uliginosa arising is not possible. The plausible explanation is that at the stage of incomplete lineages sorting, gene flow between $P$. sylvestris and $P$. mugo took place. It takes place also in the present time, what supports some level of crossability reported in natural stands. Extensive gene flow is thought to be observed in Quercus genus nowadays and despite its intensity, Quercus species are able to keep their morphological, anatomical and ecological identity (MUIR et al., 2000). As a result of large-scale changes in European floras induced by glacial history of continent, exchanging gene pools between $P$. sylvestris and $P$. mugo could have been broken down. Time and space isolation during glaciations promoted the divergence. Hybridization between Pinus sylvestris and Pinus mugo and following introgression into Pinus mugo, could have led to Pinus uliginosa arising. Consequently, peat-bog pine should be regarded as an ancient, stabilized introgressant. Biochemical, morphological and anatomical resemblances of $P$. uliginosa to $P$. mugo would be an evidence for longer and closer relationships of $P$. uliginosa with $P$. mugo complex than with P. sylvestris (SiEdLEWSKA and PrUs-GlowACKI, 1995). 
Closer relationships of $P$. uliginosa with dwarf mountain pine mirrors also reported crossability. Peat-bog pine share some traits with Scots pine due to introgression but could lost crossability due to isolation.

Based on these data and earlier studies, close phylogenetic relationship between $P$. uliginosa and $P$. mugo complex is suggested. This experiment is based on limited material and includes only one way of pollination. Therefore, in context of hypothesized P. uliginosa hybrid derivation, the obtained results unable to infer definitely about putative parental species. Reliable experiments should be founded on a more detailed material, representing more comprehensively examined populations of different species and conducted for several years to exclude influence of biotic and abiotic factors.

\section{References}

Boratyński, A., K. Boratyńska, A. LeWANDOWSKI, Z. GolA̧B and P. KosiŃsKI (2003): Evidence of the possibility of natural reciprocal crosses between Pinus sylvestris and Pinus uliginosa based on the phenology of reproductive organs. Flora 198: 377-388.

BusinskÝ, R. (1999): Taxonomic essay in the Pinus mugo complex and its hybrid population (in Czech). Acta Pruhoniciana 68: 123-143.

Christensen, K. I. (1987): Taxonomic revision of the Pinus mugo complex and $P$. $\mathrm{x}$ rhaetica $(P$. mugo $\mathrm{x}$ sylvestris) (Pinaceae). Nord. J. Bot. 7: 383-408.

DANIELEWICZ, W. and J. ZIELIŃSKI (2000): Ochrona sosny blotnej Pinus uliginosa A. Neumann na terenie Borów Dolnośląskich. Przegl. Przyr. 9: 113-124.

KORMUTAK, A. and M. LANAKOWA (1988): Biochemistry of reproductive organs and hybridological relationships of selected pine species (Pinus sp.). Acta Dendrob. 7-103.

Krzakowa, M., B. NaganowsKa and M. A. Bobowicz (1984): Investigations on taxonomic status of Pinus uliginosa Neumann. Bull. Soc. Pol. Acad. Sci. 24: 87-95.

Lewandowski, A., A. Boratyński and L. Mejnartowicz (2000): Allozyme investigations on the genetic differentiation between closely related pines - Pinus sylvestris, P. mugo, P. uncinata and P. uliginosa (Pinaceae). Pl. Syst. Evol. 221: 15-24.
Lewandowski, A., J. Samoćko, K. Boratyńska and A. BoRATYŃSKI (2002): Genetic differences between two Polish populations of Pinus uliginosa, compared to P. sylvestris and P. mugo. Dendrobiology 48: 51-57.

MarCET, E. (1967): Über den Nachweis spontaner Hybriden von Pinus mugo Turra und Pinus sylvestris auf Grund von Nedelmerkmalen. Ber. Schweiz. Bot. Ges. 77: 314-361.

Moulalis, D., C. Bassiotis and D. Mitsopoulos (1976): Controlled pollinations among Pine species in Grece. Silvae Genet. 25: 95-107.

Muir, G., C. C. Fleming and C. Schlatterer (2000): Species status of hybridizing oaks. Nature 405: 1016.

PRUs-Glowacki, W. and J. SzweYKowsKI (1980): Serological characteristics of some putative hybrid individuals from a $P$. sylvestris x $P$. mugo swarm population. Acta Soc. Bot. Pol. 49: 127-142.

Prus-Glowacki, W. and J. Szweykowski, 1983: Studies on isoenzyme variability in populations of Pinus sylvestris L., Pinus mugo Turra, Pinus uliginosa Neumann and individuals from a hybrid swarm population. Bull. Sci. Amis. Poznać. 22: 107-122.

Siedlewska, A. and W. Prus-Glowacki (1995): Genetic structure and taxonomic position of Pinus uliginosa Neumann population from Wielkie Torfowisko Batorowskie in Stolowe Mts. (Locus classicus). Acta Soc. Bot. Pol. 64: 1-8.

Staszkiewicz, J. and M. Tyszkiewicz (1969): Naturalne mieszańce Pinus mugo Turra x Pinus sylvestris L. w Kotlinie Nowotarskiej. Fragm. Flor. Geobot. 15: 187-212.

Staszkiewicz, J. (1993): Variability of Pinus mugo x $P$. sylvestris (Pinaceae) hybrid swarm in the Tisovnica nature reserve (Slovakia). Polish Bot. Stud. 5: 33-41.

WACHowiaK, W., A. BA̧CZKIEWICZ, K. CELIŃSKI and W. PRUSGLOWACKI (2004): Species-specific chloroplast DNA polymorphism in the trnV-rbcL region in Pinus sylvestris and Pinus mugo. Dendrobiology 51: 67-72.

WACHOWIAK, W., K. Celiński and W. Prus-Glowacki (2005): Evidence of natural reciprocal hybridization between Pinus uliginosa and $P$. sylvestris in sympatric population of the species. Flora 200: 563-568.

\title{
DNA From Ancient Cedar Wood From King Midas' Tomb, Turkey, and Al-Aksa Mosque, Israel
}

\author{
By S. O. Rogers ${ }^{1), 2), *)}$ and Z. KAYA ${ }^{1), 3)}$
}

(Received 22 $2^{\text {th }}$ July 2005)

\footnotetext{
1) State University of New York, College of Environmental Science and Forestry, Syracuse, NY, USA.

${ }^{2}$ ) Current Address: Department of Biological Sciences, Bowling Green State University, Bowling Green, OH, USA.

$\left.{ }^{3}\right)$ Current Address: Department of Biological Sciences, Middle East Technical University, 06531 Ankara, Turkey.

*) Corresponding author: SOR; phone: 419-372-2333; fax: 419372-2024; E-mail address: srogers@bgnet.bgsu.edu
}

\begin{abstract}
Ancient Taurus cedar (Cedrus libani A. Rich) wood samples from the Tumulus of King Midas at the Gordion archaeological site (about 2700 years old), near Ankara, Turkey, and from the Al-Aksa Mosque (about 1500 to 1900 years old), Jerusalem, Israel, were characterized by studying the sequences of ribosomal DNA (rDNA) internal transcribed spacers (ITS1 and ITS2). After
\end{abstract}

